Luisa Nunes ${ }^{1}$, Patricia Casanueva ${ }^{2 *}$, Tomás Santamaría ${ }^{3}$, María Á. Hernández ${ }^{4}$

\& Francisco Campos ${ }^{2}$

\title{
Useful biometric variables in Iberian exuviae of Boyeria irene (Fonscolombe, 1838) (Odonata: Aeshnidae)
}

\author{
https://doi.org/10.23797/2159-6719_24_12
}

Received: 5 November 2020 - Accepted: 8 February 2021 - Published: 7 July 2021

\begin{abstract}
In species of similar shape and size, biometric analyses make it possible to establish differences. Within one species, biometrics can help researchers to detect differences between populations and analyze their adaptations to environmental conditions. Until now little was known about the biometrics of the Iberian populations of Boyeria irene (Odonata: Aeshnidae), a large species living mainly in southern Europe. Eight biometric variables were studied in male and female exuviae of $B$. irene collected in three rivers of the Iberian Peninsula, with the objective of ascertaining which are the most suitable populations of this species to study. An analysis of principal components (PCA) shows that lengths of the epiproct, paraproct and prementum are the most influential in each of the three populations. The other variables (head width, body length, length of the gonapophyses, maximum and minimum width of the prementum) proved not to be relevant in this context.
\end{abstract}

Keywords: Biometrics; dragonflies; Portugal; rivers; Spain.

\section{Introduction}

Biometric analysis makes it possible to describe interspecific differences that facilitate the separation of larvae of similar insects on the basis of their appearance (Landwer \& Sites, 2006), and allows us to analyze the adaptations of some populations to environmental conditions (Hassall et al., 2008). At intraspecific level, a biometric analysis makes it possible to observe differences that would otherwise pass unnoticed. Thus, for example, the size of certain body structures in larvae of Odonata varies significantly between populations of Anax imperator Leach, 1815 living geographically very close to each other (Casanueva et al., 2017), and between populations of Cordulegaster boltonii (Donovan, 1807) living far away from each other (Casanueva et al., 2020). Whether these characteristics coincide or not with different genetic traits has not yet been proven in many species, since there is coincidence in some (Pilgrim et al., 2002) but not in others (Huang et al., 2020). Today, modern morphometric techniques allow the analysis of body structures with more precision. Establishing whether and how these structures vary (Klingenberg \& Marugán-Lobón, 2013) will help us to better understand evolutionary processes.

The larvae that emerge from the water leave behind the corresponding exuviae on the riverbanks where rheophilous odonates live (Corbet, 2004). The study of these exuviae presents numerous advantages as they are easily obtained in large numbers without excessive effort, their species can easily be identified (Doucet, 2010) and they remain in the same place for a long time (Aliberti Lubertazzi \& Ginsberg, 2009).

There are numerous variables that can be measured in exuviae and larvae (Doucet, 2010), and their selection will depend on the species being analyzed. So, for example, the lateral or back spines are measured for the purposes of studying their antipredator function (Sahlén et al., 2008; McCauley et

1 Escola Superior Agrária de Castelo Branco (ESA-IPCB/CEABN-INBIO), Qta. Sra. Mércules, 6000 Castelo Branco, Portugal.

2 Departamento de Ciencias Experimentales, Universidad Europea Miguel de Cervantes, 47012 Valladolid, Spain.

3 Universidad Católica de Ávila, Calle Canteros s/n, 05005 Ávila, Spain.

4 Departamento de Biología Ambiental, Facultad de Ciencias, Universidad de Navarra, 31080 Pamplona, Spain

* corresponding author: Email: pcasanuevaQuemc.es 
al., 2008; Leipelt et al. 2010; Johansson et al., 2017), while their prementum length can be measured to study their effectiveness in capturing prey (Lagrue et al., 2011).

Boyeria irene (Fonscolombe, 1838) (Odonata: Aeshnidae) is a large species (total length of larvae $3-4 \mathrm{~cm}$ in the final stage of development, designated as F-0), which makes finding its exuviae easy. It is distributed mainly in Mediterranean Europe (Boudot et al., 2009), where it occupies the rivers of mountain ranges, often associated with a few species of other anisopteres such as Cordulegaster boltonii, Onychogomphus forcipatus (Linnaeus, 1758) and O. uncatus (Charpentier, 1840) (Ocharan $\&$ Torralba Burrial, 2004). It is a semivoltine or partivoltine species (Ferreras-Romero, 1997; Velasco et al., 2018), with a pattern of emergence suitable for a summer species (sensu Corbet, 1954, 1964). Its larval cycle was analyzed by Ferreras-Romero (1997), who established several stages of development combining the head width with the length of the wing sheaths. The morphology and biometry of B. irene larvae in Europe has been analyzed by Wenger (1959), Wildermuth (2005) and Müller et al. (2012), among others. Müller et al. (2012) proposed five measures (lengths of body, abdomen, cerci, paraproct and epiproct) that distinguish the larvae of $B$. irene and $B$. cretensis. In the Iberian Peninsula very little is known about its larval biometry, except for the work cited by Ferreras-Romero (1997) related to larval stages, and the length of exuviae provided by Prunier (2005). Nothing is known about the possible geographic variation with respect to its biometrics in Iberian populations.

The aim of this work is to analyze some biometric variables in B. irene, usually taken in exuviae, with the objective of ascertaining which are the most appropriate ones to study Iberian populations. This is a preliminary step to the analysis of the biometric variation of these populations, which can show differences and similarities, as is the case with Cordulegaster boltonii (Casanueva et al., 2020). In our case, we established two conditions that the populations chosen for study must meet: 1) they must be geographically isolated; 2) the values of the variables analyzed must differ between populations, to ensure in this way that a wide spectrum of sizes is covered. For the variables to be useful in a later study on a wider geographic scale, there should be two or three variables that are representative within each population, taking into account gender-related differences in size. Furthermore, in order for these variables to be used, they must be the same in the populations analyzed.

\section{Material and methods}

Exuviae samples were gathered in three rivers of the Iberian Peninsula, chosen for being in zones of different climatology and altitude: one in Portugal (River Cova) and the others in Spain (Rivers Frío and Eresma). Their characteristics are summarized in Table 1. The geographical distances are 171 $\mathrm{km}$ between Cova and Frío, $228 \mathrm{~km}$ between Frío and Eresma, and $325 \mathrm{~km}$ between Cova and Eresma. Sampling was carried out in June, 2013 (Frío and Eresma) and in June, 2015 (Cova), by carefully inspecting the substrates (ground, emergent vegetation, stones, tree trunks, logs, etc.) located in the river banks.

Table 1. Some characteristics of the three sampled rivers. Tm: annual mean temperature. R: annual precipitation. Tm and R from Ninyerola et al. (2005).

\begin{tabular}{|l|l|l|l|}
\hline & Cova & Frío & Eresma \\
\hline Municipality & Ribeira de Pena & Villasrubias & San Ildefonso \\
\hline Coordinates & $41.5821^{\circ} \mathrm{N}$ & $40.3154^{\circ}{ }^{\circ} \mathrm{N}$ & $40.8488^{\circ} \mathrm{N}$ \\
& $7.7847^{\circ} \mathrm{W}$ & $6.6347^{\circ} \mathrm{W}$ & $4.0179^{\circ} \mathrm{W}$ \\
\hline Altitude (m a.s.1.) & 495 & 830 & 1200 \\
\hline $\operatorname{Tm}\left({ }^{\circ} \mathrm{C}\right)$ & 12.9 & 12.6 & 10.4 \\
\hline $\mathrm{R}(\mathrm{mm})$ & 1009 & 1044 & 835 \\
\hline
\end{tabular}


The following variables were measured in each exuvia according to the criteria established by Wenger (1959): head width (HW); body length (BL), obtained only on straight exuviae, without curvatures produced during ecdysis; paraproct length (PA); epiproct length (EP); gonapophyses length (GO, only in females); maximum prementum width (W+); minimum prementum width (W-); prementum length (PR). They are all expressed in $\mathrm{mm}$ and were obtained by the same person (FC) with a stereo microscope equipped with a millimetre eyepiece, except for BL, measured with a $0.01 \mathrm{~mm}$ precision digital calliper.

No attempt was made to measure the length of the cerci because $B$. irene presents two morphs: brachycerca (short cerci) and typica (long cerci) (Wenger 1959), which can only be observed in females and this dimorphism varies widely between populations (Mikolajewski et al., 2000; FerrerasRomero \& Suhling, 2021). For each biometric variable, normality tests (Shapiro-Wilk) and homogeneity (Barlett's) test were performed. When these conditions were fulfilled, variables were compared based on genders and among rivers through ANOVA, and when they were not fulfilled, they were compared using the Kruskal-Wallis test. These calculations were made by STATA 12.1 software. Furthermore, an analysis of principal components (PCA) was carried out to establish which variables identify each population best, and those variables were logarithmically transformed. Likewise, the three studied populations were compared by means of another PCA. These calculations were carried out using the Past 3.15 pro software (Hammer et al., 2001).

\section{Results}

A total of 356 exuviae were collected, 218 in River Cova (94 males, 124 females), 83 in River Frío (30 males, 53 females) and 55 in River Eresma (21 males, 34 females). The average values and standard deviation of measured variables are included in Table 2.

Table 2. Mean values \pm SD of the variables obtained in male and female exuviae of Boyeria irene from the Cova, Frío and Eresma rivers. In parentheses, range of values. HW: head width. BL: body length. PA: length of the paraproct. EP: length of epiproct. GO: length of the gonapophyses. W+: maximum width of the prementum. W-: minimum width of the prementum. PR: length of the prementum. All measurements in $\mathrm{mm}$.

\begin{tabular}{|l|l|l|l|l|l|l|}
\hline & Male & Male & Male & Female & Female & Female \\
\hline & Cova & Frío & Eresma & Cova & Frío & Eresma \\
\hline HW & $\begin{array}{l}8.07 \pm 0.16 \\
(7.65-8.40)\end{array}$ & $\begin{array}{l}7.79 \pm 0.20 \\
(7.30-8.25)\end{array}$ & $\begin{array}{l}7.95 \pm 0.15 \\
(7.70-8.20)\end{array}$ & $\begin{array}{l}8.33 \pm 0.16 \\
(7.80-8.70)\end{array}$ & $\begin{array}{l}8.08 \pm 0.31 \\
(7.30-9.00)\end{array}$ & $\begin{array}{l}8.21 \pm 0.15 \\
(7.90-8.55)\end{array}$ \\
\hline BL & $\begin{array}{l}36.24 \pm 1.15 \\
(33.10-38.94)\end{array}$ & $\begin{array}{l}36.75 \pm 1.15 \\
(34.26-39.12)\end{array}$ & $\begin{array}{l}37.80 \pm 1.28 \\
(35.41-39.88)\end{array}$ & $\begin{array}{l}37.91 \pm 1.14 \\
(35.08-41.07)\end{array}$ & $\begin{array}{l}37.08 \pm 1.55 \\
(34.17-40.51)\end{array}$ & $\begin{array}{l}39.15 \pm 1.15 \\
(37.41-41.94)\end{array}$ \\
\hline PA & $\begin{array}{l}3.92 \pm 0.14 \\
(3.60-4.40)\end{array}$ & $\begin{array}{l}3.82 \pm 0.15 \\
(3.50-4.15)\end{array}$ & $\begin{array}{l}3.83 \pm 0.13 \\
(3.60-4.05)\end{array}$ & $\begin{array}{l}4.00 \pm 0.13 \\
(3.60-4.25)\end{array}$ & $\begin{array}{l}3.86 \pm 0.25 \\
(3.30-4.40)\end{array}$ & $\begin{array}{l}3.93 \pm 0.18 \\
(3.60-4.30)\end{array}$ \\
\hline EP & $\begin{array}{l}2.88 \pm 0.16 \\
(2.50-3.35)\end{array}$ & $\begin{array}{l}2.70 \pm 0.19 \\
(2.30-3.10)\end{array}$ & $\begin{array}{l}2.92 \pm 0.13 \\
(2.70-3.25)\end{array}$ & $\begin{array}{l}2.84 \pm 0.14 \\
(2.50-3.15)\end{array}$ & $\begin{array}{l}2.71 \pm 0.24 \\
(2.20-3.50)\end{array}$ & $\begin{array}{l}2.85 \pm 0.14 \\
(2.60-3.20)\end{array}$ \\
\hline GO & & & $\begin{array}{l}3.36 \pm 0.11 \\
(3.00-3.60)\end{array}$ & $\begin{array}{l}3.33 \pm 0.17 \\
(2.90-3.60)\end{array}$ & $\begin{array}{l}3.51 \pm 0.11 \\
(3.25-3.80)\end{array}$ \\
\hline W+ & $\begin{array}{l}4.28 \pm 0.11 \\
(4.00-4.65)\end{array}$ & $\begin{array}{l}4.11 \pm 0.13 \\
(3.90-4.35)\end{array}$ & $\begin{array}{l}4.16 \pm 0.13 \\
(3.90-4.40)\end{array}$ & $\begin{array}{l}4.43 \pm 0.10 \\
(4.20-4.70)\end{array}$ & $\begin{array}{l}4.21 \pm 0.17 \\
(3.90-4.50)\end{array}$ & $\begin{array}{l}4.31 \pm 0.12 \\
(4.05-4.55)\end{array}$ \\
\hline W- & $\begin{array}{l}2.33 \pm 0.07 \\
(2.15-2.55)\end{array}$ & $\begin{array}{l}2.25 \pm 0.09 \\
(2.00-2.45)\end{array}$ & $\begin{array}{l}2.29 \pm 0.07 \\
(2.20-2.40)\end{array}$ & $\begin{array}{l}2.41 \pm 0.08 \\
(2.20-2.60)\end{array}$ & $\begin{array}{l}2.27 \pm 0.12 \\
(2.00-2.50)\end{array}$ & $\begin{array}{l}2.38 \pm 0.06 \\
(2.30-2.55)\end{array}$ \\
\hline PR & $\begin{array}{l}6.48 \pm 0.21 \\
(5.90-6.90)\end{array}$ & $\begin{array}{l}5.94 \pm 0.43 \\
(5.12-6.70)\end{array}$ & $\begin{array}{l}6.22 \pm 0.19 \\
(5.70-6.60)\end{array}$ & $\begin{array}{l}6.69 \pm 0.18 \\
(6.05-7.10)\end{array}$ & $\begin{array}{l}6.14 \pm 0.42 \\
(5.40-7.25)\end{array}$ & $\begin{array}{l}6.43 \pm 0.17 \\
(6.15-6.80)\end{array}$ \\
\hline
\end{tabular}


All variables were adjusted to normality and homogeneity, and all were significantly larger in females than in males, except for the epiproct in the River Cova (Table 3). In the River Frío, all variables were adjusted to normality and homogeneity except $\mathrm{HW}, \mathrm{BL}$ and PA. In this case, variables $\mathrm{HW}, \mathrm{W}+$ and PR were significantly larger in females than males (Table 3). In the River Eresma, all variables were adjusted to normality and homogeneity, except BL. All variables were significantly larger in females than in males, except the epiproct, which was similar in both genders in the River Cova (Table 3).

Table 3. Values of the comparison test of the variables between male and female exuviae of Boyeria irene in the Rivers Cova, Frío and Eresma rivers. HW: head width. BL: body length. PA: length of the paraproct. EP: length of epiproct. W+: greater width of the prementum. W-: smaller width of the prementum. PR: length of the prementum. F: ANOVA. H: Kruskal-Wallis test. $P=$ probability.

\begin{tabular}{|l|l|l|l|}
\hline & Cova & Frío & Eresma \\
\hline HW & $\mathrm{F}=153.56$ & $\mathrm{H}=31.026$ & $\mathrm{~F}=38.88$ \\
& $\mathrm{P}=0.000$ & $\mathrm{P}=0.000$ & $\mathrm{P}=0.000$ \\
\hline BL & $\mathrm{F}=113.27$ & $\mathrm{H}=0.313$ & $\mathrm{~F}=4.76$ \\
& $\mathrm{P}=0.000$ & $\mathrm{P}=0.576$ & $\mathrm{P}=0.033$ \\
\hline PA & $\mathrm{F}=18.61$ & $\mathrm{H}=1.554$ & $\mathrm{~F}=4.76$ \\
& $\mathrm{P}=0.000$ & $\mathrm{P}=0.209$ & $\mathrm{P}=0.033$ \\
\hline EP & $\mathrm{F}=2.79$ & $\mathrm{~F}=0.80$ & $\mathrm{~F}=3.47$ \\
& $\mathrm{P}=0.097$ & $\mathrm{P}=0.374$ & $\mathrm{P}=0.068$ \\
\hline W+ & $\mathrm{F}=102.37$ & $\mathrm{~F}=9.69$ & $\mathrm{~F}=16.14$ \\
& $\mathrm{P}=0.000$ & $\mathrm{P}=0.002$ & $\mathrm{P}=0.000$ \\
\hline W- & $\mathrm{F}=70.12$ & $\mathrm{~F}=1.01$ & $\mathrm{~F}=26.38$ \\
& $\mathrm{P}=0.000$ & $\mathrm{P}=0.316$ & $\mathrm{P}=0.000$ \\
\hline PR & $\mathrm{F}=66.61$ & $\mathrm{~F}=10.025$ & $\mathrm{~F}=17.72$ \\
& $\mathrm{P}=0.000$ & $\mathrm{P}=0.001$ & $\mathrm{P}=0.000$ \\
\hline
\end{tabular}

In males and females the values of the variables measured in the exuviae varied significantly between the three rivers (Table 4).

Table 4. Comparison between the three rivers analysed in terms of the variables measured in exuviae of Boyeria irene. Each sex is analysed separately. H: Kruskal-Wallis test. F: ANOVA. P: probability.

\begin{tabular}{|l|l|l|l|l|}
\hline & Male & & Female & \\
\hline & Test & $\mathrm{P}$ & Test & $\mathrm{P}$ \\
\hline $\mathrm{HW}$ & $\mathrm{F}=32.78$ & 0.00001 & $\mathrm{H}=48.60$ & 0.0001 \\
\hline $\mathrm{BL}$ & $\mathrm{F}=15.70$ & 0.00001 & $\mathrm{H}=44.48$ & 0.0001 \\
\hline $\mathrm{PA}$ & $\mathrm{F}=7.26$ & 0.001 & $\mathrm{H}=18.02$ & 0.0001 \\
\hline EP & $\mathrm{F}=14.41$ & 0.00001 & $\mathrm{H}=19.10$ & 0.0001 \\
\hline $\mathrm{GO}$ & & & $\mathrm{H}=37.65$ & 0.0001 \\
\hline $\mathrm{W}+$ & $\mathrm{F}=26.14$ & 0.00001 & $\mathrm{H}=63.17$ & 0.0001 \\
\hline $\mathrm{W}-$ & $\mathrm{F}=17.21$ & 0.00001 & $\mathrm{H}=55.17$ & 0.0001 \\
\hline PR & $\mathrm{H}=44.05$ & 0.0001 & $\mathrm{H}=81.58$ & 0.0001 \\
\hline
\end{tabular}


In the PCA analyzing the three rivers together, $\mathrm{PC} 1$ and $\mathrm{PC} 2$ component values for variance were: a) for River Cova $58.87 \%$ and $18.06 \%$ in males, $51.60 \%$ and $14.00 \%$ in females; b) for River Frío $56.62 \%$ and $20.86 \%$ in males, $59.74 \%$ and $14.63 \%$ in females; c) for River Eresma $57.70 \%$ and $23.35 \%$ in males, $56.90 \%$ and $15.31 \%$ in females.

According to $\mathrm{PCl}$ values (Figure 1), epiproct is the variable with greater significance in males from the Rivers Cova and Eresma, while the length of the prementum had the greatest significance in males from the River Frío. In females, epiproct and prementum were the variables with greater significance in River Frío, and epiproct and paraproct in the River Cova. For the River Eresma epiproct and paraproct had similar values. The significance of the rest of the variables changed depending on the rivers.

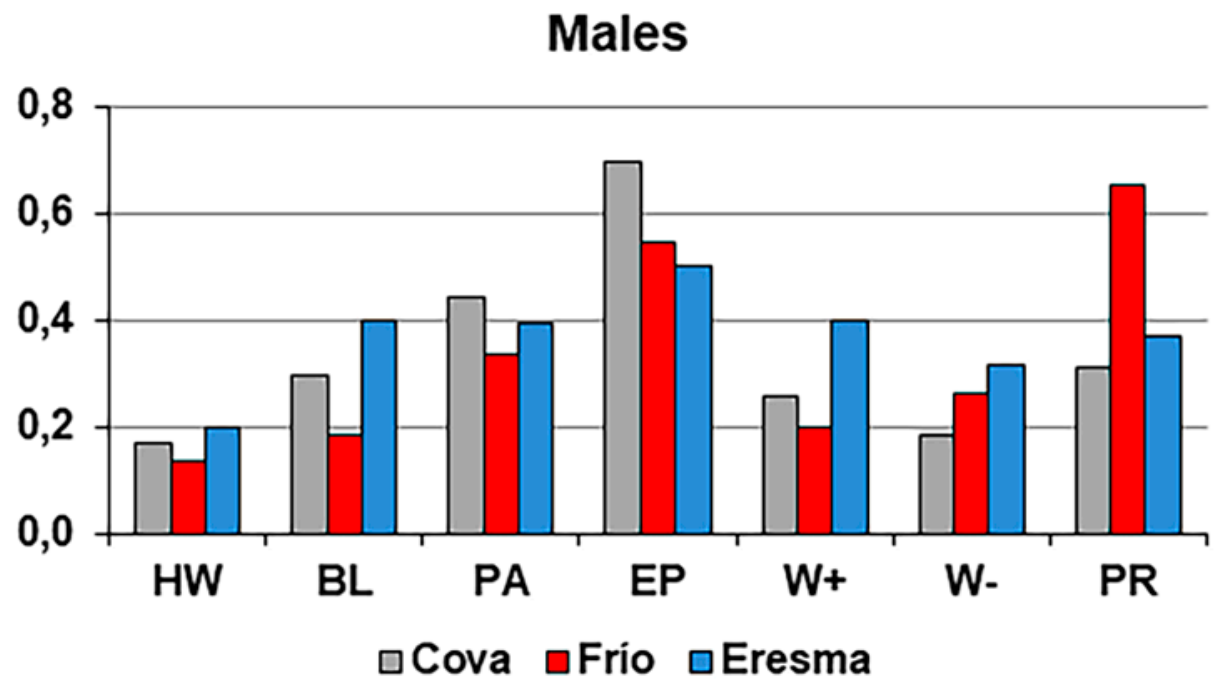

Females

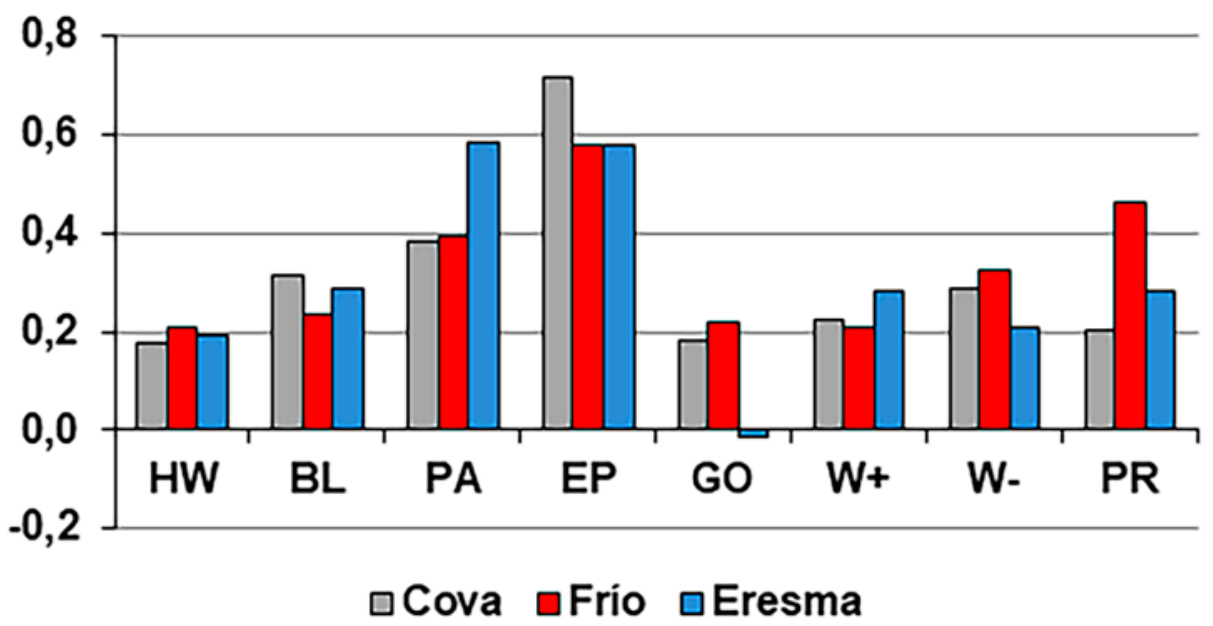

Figure 1. Values of the loading of the variables in PCA 1 of male and female exuviae of Boyeria irene in each sampled river. HW: head width. BL: body length. PA: length of the paraproct. EP: length of epiproct. W+: greater width of the prementum. W-: smaller width of the prementum. PR: length of the prementum. All variables were logarithmically transformed. 
For males from the three rivers, the components PC1 and PC2 (Figure 2) explained 59.07\% and $12.75 \%$ of the variance, respectively. With respect to PC1 all variables were located on the positive side, while with respect to PC2 the variables $\mathrm{HW}$, and the three for the prementum (PR, $\mathrm{W}+$ and $\mathrm{W}-)$ were on the positive side, and the variables BL, PA and EP were on the negative side. This implies that PC2 discriminates variables relating to the head rather than variables concerning the rest of the body. With respect to PC1 (Figure 2), on the negative side were found the exuviae from the River Frío, which have the lowest value for all the variables except BL. The exuviae from the Rivers Cova and Eresma were not different on this axis, because there was no clear difference between the two sites for the variables measured as a whole. Regarding PC2, the exuviae from the Rivers Cova and Eresma were clearly separate: on the positive side were found those from the River Cova, which have the largest values for HW, PR, W+ and W-, and the lowest values for BL and EP.

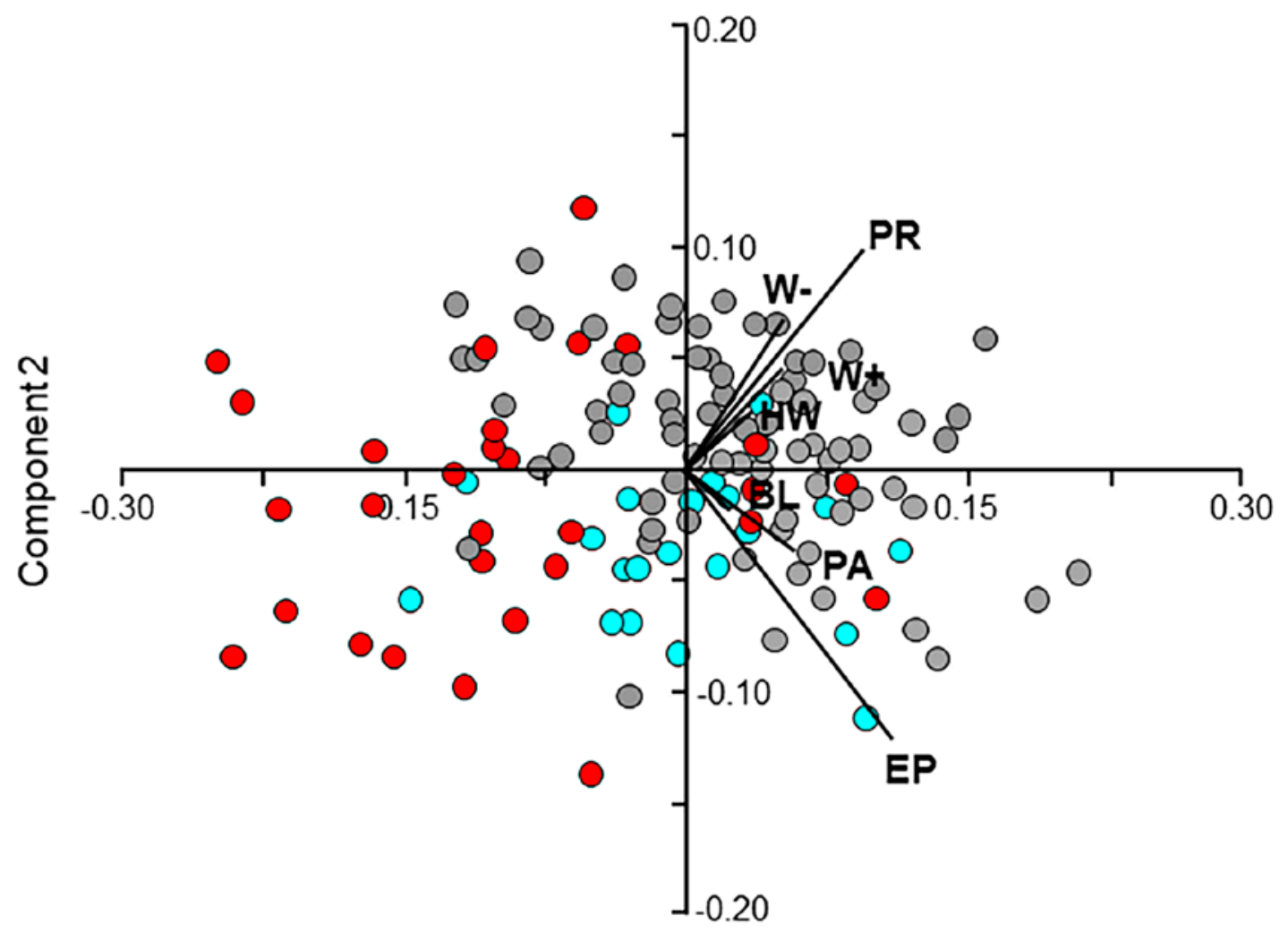

\section{Component 1}

Figure 2. PCA of male exuviae of Boyeria irene in the Rivers Cova (grey points), Frío (red points) and Eresma (blue points). HW: head width. BL: body length. EP: length of epiproct. PA: length of the paraproct. W+: maximum width of the prementum. W-: minimum width of the prementum. PR: length of the prementum. All variables were logarithmically transformed.

For females (Figure 3 ) the PC1 and PC2 components explained $59.49 \%$ and $16.53 \%$ of variance, respectively. With respect to $\mathrm{PC1}$, all variables were located on the positive side. For PC2, the variables $\mathrm{HW}, \mathrm{PR}, \mathrm{W}+$ and $\mathrm{W}$ - were on the positive side, as was also the case in the males, but they differed from the males in that BL was on the positive side. Finally, GO was also on the positive side in PC2. With respect to populations, the exuviae from the River Frío were again located on the negative side of PC1 with the lowest values of all variables. The exuviae from the River Eresma were plotted around the intersection of the two axes, while those of the River Cova tended to the positive side on PC1 and PC2, possibly influenced by the greater length of the prementum, which has a higher value in the River Cova than the River Eresma. 


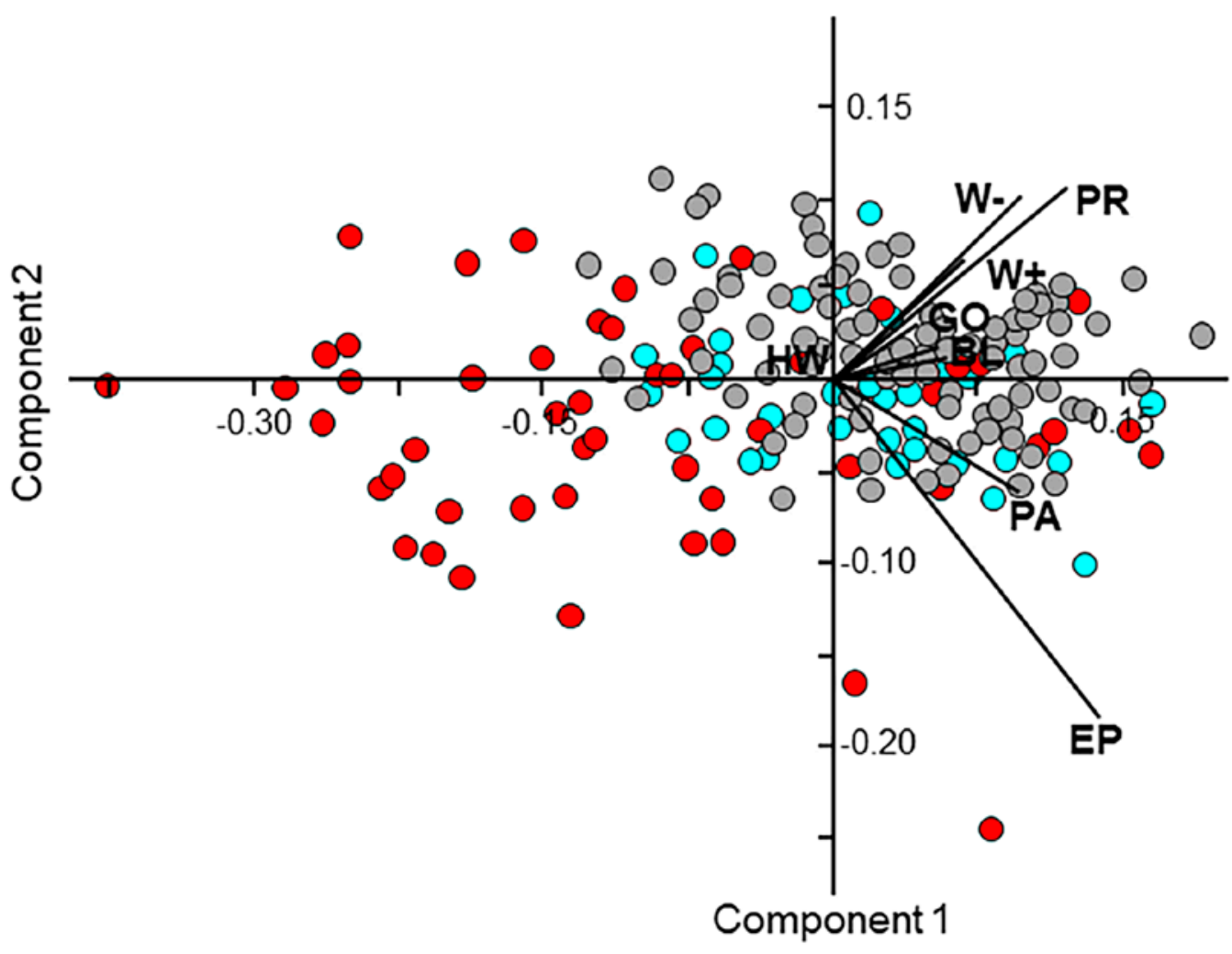

Figure 3. PCA of female exuviae of Boyeria irene in the Rivers Cova (grey points), Frío (red points) and Eresma (blue points). HW: head width. BL: body length. EP: length of epiproct. PA: length of the paraproct. W+: maximum width of the prementum. W-: minimum width of the prementum

\section{Discussion}

Exuviae collected in the three sites fulfilled the previously established condition of differing in size among rivers. There were three variables (epiproct, paraproct and prementum) that stood out over others in the PCA and, therefore, could be considered representative in these populations. This was true for males and females. Furthermore, these three variables coincided in the three rivers analyzed. Therefore, in order to biometrically analyze $B$. irene populations in the Iberian Peninsula, the best variables analyzed here were the epiproct, paraproct and prementum.

Epiproct, paraproct and prementum have been used previously in the taxonomies of odonates (see, among many others, Heidemann \& Seidenbusch, 2002; Doucet, 2010; Tennessen, 2019). Their morphology and/or length aid differentiation between the species of various genera, above all in the way they join onto other body structures, such as in the genus Ladona (Tennessen et al., 2017). Often the length of the epiproct relative to the length of the paraproct is a great help for identifying the species correctly, as is the case with the genus Tramea (Landwer \& Sites, 2005) and other genera distributed in the Palearctic (Doucet, 2010). However, less attention has been paid to the intraspecific biometric variation in odonate larvae. In this sense, larval morphological characters vary with the habitat type occupied (Sahlén et al., 2008). Larvae living on the bottoms of streams, as is the case with $B$. irene (Velasco et al., 2018), may invest less in direct foraging organs (Giacomini \& De Marco, 2008) and more in an effective system for reducing predation risk. In the populations analyzed in this study, the variables PR, EP and PA varied significantly between rivers, suggesting possible local adaptations to 
environmental conditions. It is important to know the biometric differences between populations well, because variations in body size could play a role during competition for resources in adult and larval stages (Bowman et al., 2018; Minot et al., 2019). There is no doubt that knowing the morphological differences between populations better would help us to improve our management and conservation of the various odonates species (Tennessen, 2019). In the genus Boyeria, Müller et al. (2012) also refer to epiproct and paraproct as useful variables in interspecific analysis between $B$. irene and $B$. cretensis. Our data confirm that, in addition, these variables are valid for intraspecific analysis in this case, at least for $B$. irene, and that they could be used to analyze variations in populations of this species.

In the present study, the other variables analyzed in the exuviae of $B$. irene do not appear to be of value in this sense. Head width (HW) has been used to establish which instar $B$. irene larvae belong to (Ferreras-Romero, 1997), but the value of this variable changes on many occasions during ecdysis because the opening of the cuticle happens in an area of the body near the head (Corbet, 2004). This detracts from its value as a variable that is suitable for the biometric analysis of exuviae. Body length (BL) is an easy measurement to obtain for exuviae in situ, because it only requires a digital calliper. But there are other data that have significant importance in the set of variables when the three rivers are analyzed together. Furthermore, the intersegmental skins of the exuviae can be stretched out at emergence or not, and so the BL produces high variance. Consequently, BL is not suitable for the biometric characterization of $B$. irene populations, and should not be used in population analysis, at least for the Iberian Peninsula. The length of the gonapophyses (GO) is valid for separating Iberian and North African populations of Cordulegaster boltonii (Casanueva et al., 2020), but in B. irene it is of little importance, since its value in the PCA is the smallest of all, and is therefore not useful for population analysis. The size of the gonapophyses in anisoptera larvae varies between species (Heidemann \& Seidenbusch, 2002), but up till now this feature has not been used to study populations. On the other hand, adult female genitalia of dragonflies have been widely used for taxonomies, phylogenetics, etc. (see, for example, Matushkina, 2011 and the references cited there). Clearly, more research is needed to establish whether the gonapophyses in larvae of different species is a valid structure for conducting population research. Finally, the variables $\mathrm{W}+$ and $\mathrm{W}$ - have been proposed for taxonomic study of larvae and exuviae in Anisoptera (Doucet, 2010, among others). However, Casanueva et al. (2017) and El Haissoufi et al. (2018) have shown that in C. boltonii these are not efficient variables to use for intraspecific biometric analyses. Our results confirm that they should not be used to this end in $B$. irene either.

Some authors have differentiated between genera and species of odonates by combining morphological data and molecular analyses (Torres-Pachón et al., 2017; Baskinger et al., 2008; Hovmöller \& Johansson, 2003). In B. irene Kohli et al. (2014) found that the populations present in NW Spain (Galicia) could be genetically differentiated from those of the rest of the Iberian Peninsula but these researchers did not compare biometric data. If the three measures that we propose in this work are valid for the population of Galicia, it is something that requires further research.

\section{Acknowledgements}

The authors would like to thank Begoña Tens, Amilcar Teixeira, Tatiana Velasco and Germán Sanz who provided considerable assistance in the field work. Dr Manuel Ferreras-Romero commented on and improved the first version of this paper. We also thank two anonymous reviewers for helpful comments that considerably improved the first version of this paper submitted. 


\section{References}

Aliberti Lubertazzi, M. A. \& Ginsberg, H. S. (2009). Persistence of dragonfly exuviae on vegetation and rock substrates. Northeastern Naturalist, 16, 141-147.

Baskinger, G. M., Ware, J. L., Kornell, D. D., May, M. L., \& Kjer, K. M. (2008). A phylogeny of Celithemis inferred from mitochondrial and nuclear DNA sequence data and morphology (Anisoptera: Libellulidae). Odonatologica, 37, 101-109.

Boudot, J. P., Kalkman, V. J., Azpilicueta Amori, N. M., Bogdanovic, T., Cordero Rivera, A., Degabriele, G., Dommanget, J. L., Ferreira, S., Garrigos, B., Jovic, M. et al. (2009). Atlas of the Odonata of the Mediterranean and North Africa. Libellula (Suppl.) 9, 256 pp.

Bowman, R. M., Schmidt, S., Weeks, C., Clark, H., Brown, C., Latta IV L. C. \& Edgehouse, M. (2018). Phenotypic plasticity in a population of odonates. Scientific Reports, 8, 8442. DOI: 10.1038/s41598-018-26301-y

Casanueva, P., Carpintero, P., Hernández, M. A., Santamaría, T. \& Campos, F. (2017). Un análisis biométrico en exuvias de Anax imperator Leach, 1815 (Odonata, Aeshnidae) en lagunas de la provincia de Salamanca, España. Boletín de la Asociación Española de Entomología, 41, 197-210.

Casanueva, P., Santamaría, T., Hernández, M. A., Sánchez-Sastre, L. F., Teixeira, A., Bennas, N., El Haissoufi, M., Ferreras-Romero, M. \& Campos, F. (2020). Biometric differences in Iberian and Maghrebi populations of Cordulegaster boltonii (Odonata: Cordulegastridae). European Journal of Entomology, 117, 260-264. doi: 10.14411/eje.2020.028

Corbet, P. S. (1954). Seasonal regulation in British dragonflies. Nature, 174, 655.

Corbet P. S. (1964). Temporal patterns of emergence in aquatic insects. Canadian Entomologist, 96, 264-279.

Corbet, P.S. (2004). Dragonflies: Behaviour and Ecology of Odonata. Revised Edition. Colchester : Harley Books.

Donovan, E. (1807). The Natural History of British Insects (Vol. 12). London : Author.

Doucet, G. (2010). Clé de détermination des exuvies des odonates de France. Bois-d'Arcy : Société Française d'Odonatologie.

El Haissoufi, M., Bennas, N., Hernández, M. A., Casanueva, P. \& Campos F. (2018). Biometrics of exuviae of Cordulegaster boltonii algirica Morton, 1916 (Odonata: Cordulegastridae). Aquatic Insects, 39, 407-413. DOI: 10.1080/01650424.2018.14767

Ferreras-Romero, M. (1997). The life cycle of Boyeria irene (Fonscolombe, 1838) (Odonata: Aeshnidae) in the Sierra Morena Mountains (southern Spain). Hydrobiologia, 345, 109-116.

Ferreras-Romero, M. \& Suhling, F. (2021). On the dimorphism shown by the females of Boyeria irene (Odonata: Aeshnidae) in a southern Spain population. Libellula Supplement (in press), 16, 115-125.

Fonscolombe, B. (1838). Monographie des Libellulines des environs d'Aix. Annales de la Société Entomologique de France, 7, 75-106.

Giacomini, H. C. \& De Marco Jr, P. (2008). Larval ecomorphology of 13 Libellulidae (Anisoptera, Odonata) of the Middle Rio Doce Valley, Minas Gerais, Brazil. Brazilian Journal of Biology, 68, 211-219.

Hammer, R., Harper, D. A. T. \& Ryan P. D. (2001). PAST: Paleontological statistics software package for education and data analysis. Paleontologia Electronica, 4, 1-9.

Hassall, C., Thompson, D. J. \& Harvey I. F. (2008). Latitudinal variation in morphology in two sympatric damselfly species with contrasting range dynamics (Odonata: Coenagrionidae). European Journal of Entomology, 105, 939-944.

Heidemann, H. \& Seidenbusch, R. (2002). Larves et exuvies des libellules de France et d'Allemagne. Bois-d'Arcy : Société Française d'Odonatologie.

Hovmöller, R., \& Johansson, F. (2002). A phylogenetic perspective on larval spine morphology in Leucorrhinia (Odonata: Libellulidae) based on ITS1, 5.8S, and ITS2 rDNA sequences. Molecular Phylogenetics and Evolution, 30, 653-662. DOI:10.1016/S1055-7903(03)00226-4

Huang, S. T., Wang, H. R., Yang, W. Q., Si Y. C., Wang Y. T., Sun M. L., Qi X. \& Bai Y. (2020). Phylogeny of Libellulidae (Odonata: Anisoptera): comparison of molecular and morphology-based phylogenies based on wing morphology and migration. PeerJ8, e8567. http://doi.org/10.7717/ peerj. 8567 
Johansson, F., Halvarsson, P., Mikolajewski, D. J., Höglund, J. (2017). Phylogeography and larval spine length of the dragonfly Leucorhinia dubia in Europe. PLoS ONE, 12(9), e0184596. https:// doi.org/10.1371/journal.pone.0184596

Klingenberg, C. P. \& Marugán-Lobón, J. (2013). Evolutionary covariation in geometric morphometric data: analyzing integration, modularity, and allometry in a phylogenetic context. Systematic Biology, 62, 591-610.

Kohli, M. K., Schneider, T., Müller, O. \& Ware, J. L. (2014). Counting the spots: a molecular and morphological phylogeny of the spotted darner Boyeria (Odonata: Anisoptera: Aeshnidae) with an emphasis on European taxa. Systematic Entomology, 39, 190-195. DOI: 10.1111/ syen.12049

Lagrue, C., Azémar, F., Besson, A., Lamothe, S. \& Lecerf, A. (2011). Novel ligature methods for studying sublethal effects of sit-and-wait predators: test using Cordulegaster boltonii (Donovan, 1807) larvae (Anisoptera: Cordulegastridae). Odonatologica, 40, 95-103.

Landwer, B. H. P. \& Sites, R. W. (2005). Diagnostic efficacy of morphological characters of larval Tramea lacerata Hagen and Tramea onusta Hagen (Odonata: Libellulidae) in the Prairie Region of Missouri. The Great Lakes Entomologist, 38, 155-163.

Landwer, B. H. P. \& Sites, R. W. (2006). Variability in larval character states used to distinguish between species of Pantala hagen (Odonata: Libellulidae). Florida Entomologist, 89, 354-360. https://doi.org/10.1653/0015-4040(2006)89[354:VILCSU]2.0.CO;2

Leipelt, K. G., Suhling, F., \& Gorb, S. N. (2010). Ontogenetic shifts in functional morphology of dragonfly legs (Odonata: Anisoptera). Zoology, 113, 317-325.

Matushkina, N. A. (2011). Morphology of exophytic ovipositors in dragonflies (Odonata: Gomphidae, Corduliidae, Libellulidae), with particular reference to ovipositor muscles and sensilla. International Journal of Odonatology, 14, 233-248. DOI: 10.1080/13887890.2011.613736

McCauley, S. J., Davis, C. J. \& Werner, E. (2008). Predator induction of spine length in larval Leucorrhinia intacta (Odonata). Evolutionary Ecology Research, 10, 435-447.

Mikolajewski, D. J., Miksche, D., Leipelt, K. G., \& Suhling, F. (2000). Weibchenpolymorphismus, Geschlechterverhältnis und Größenunterschiede in französischen Populationen von Boyeria irene (Odonata: Aeshnidae). Libellula, 19: 1-15.

Minot, M., Le Gall, M. \& Husté, A. (2019). Biometry of the large dragonfly Anax imperator (Odonata: Aeshnidae): A study of traits from larval development to adults. European Journal of Entomology, 116, 269-280. doi: 10.14411/eje.2019.031

Müller, O., Taron, U., Jansen, A. \& Schneider, T. (2012). Description of the larva of Boyeria cretensis Peters and comparison with B. irene (Fonscolombe) (Anisoptera: Aeshnidae). Odonatologica, 41, $47-54$.

Ninyerola, M., Pons, X. \& Roure, J. M. (2005). Atlas Climático Digital de la Península Ibérica. Metodología y aplicaciones en bioclimatología y geobotánica. Bellaterra: Universidad Autónoma Barcelona.

Ocharan, F. J. \& Torralba Burrial, A. (2004). La relación entre los odonatos y la altitud: el caso de Asturias (Norte de España) y la Península Ibérica (Odonata). Boletín SEA, 35, 103-116.

Pilgrim, E. M., Roush, S. A. \& Krane, D. E. (2002). Combining DNA sequences and morphology in systematics: testing the validity of the dragonfly species Cordulegaster bilineata. Heredity, 89, 184-190.

Prunier, F. (2005). Sex ratio y biometría en tres poblaciones de libélulas de Sierra Morrena: Anax imperator, Boyeria irene, Cordulegaster boltonii immaculifrons (Insecta: Odonata). Boletín de la Sociedad Entomológica de Andalucía, 13, 67-71.

Sahlén, G., Haase, S. \& Suhling, F. (2008). Morphology of dragonfly larvae along a habitat gradient: interactions with feeding behaviour and growth (Odonata: Libellulidae). International Journal of Odonatology, 11, 225-240.

Tennessen, K. J. (2019). Dragonfly nymphs of North America: An identification guide. Cham: Springer. https://doi.org/10.1007/978-3-319-97776-8

Tennessen, K. J., DuBois, R. B. \& Hemeon, K. (2017). Description of the last stadium nymph of Ladona exusta (Say) (Odonata: Libellulidae). Entomologica Americana, 123, 1-8. DOI: 10.1664/19475144-123.1-4.1 
Torres-Pachón, M., Novelo-Gutiéerrez, R. \& de los Monteros, A. E. (2017). Phylogenetic analysis of the genus Argia Rambur, 1842 (Odonata: Coenagrionidae), based on morphological characters of larvae and mitochondrial DNA sequences. Organisms Diversity and Evolution, 17, 1-12. DOI 10.1007/s13127-017-0325-7

Velasco, T., Norling, U., Campos, F. \& Ferreras-Romero, M. (2018). The life cycles of Boyeria irene and Onychogomphus uncatus (Odonata: Aeshnidae, Gomphidae) in western Spain: a biometric study. European Journal of Entomology, 115, 684-696. DOI: 10.14411/eje.2018.067

Wenger, O. P. (1959). Die beiden + Formen von Boyeria irene (Odonata-Aeschnidae). Mitteilungen der Schweizerischen Entomologischen Gesellschaft, 23, 304-311.

Wildermuth, H. (2005). Beitrag zur Larvalbiologie von Boyeria irene (Odonata: Aeshnidae). Libellula, 24, 1-30. 